\title{
AKTIVITAS INHIBISI ENZIM $\alpha$-GLUKOSIDASE EKSTRAK AIR DAN ETANOL UMBI LAPIS BAWANG MERAH (Allium ascalonicum)
}

\author{
Sitaresmi Yuningtyas, Dian Setiawati Artianti \\ Program Studi Farmasi, Sekolah Tinggi Teknologi Industri dan Farmasi Bogor \\ Email:sitaresmi_yuningtyas@yahoo.com
}

\begin{abstract}
ABSTRAK
Umbi lapis bawang merah (Allium ascalonicum) mempunyai potensi sebagai analgesik, antiinflamasi, antimikobakterial, antifungi, dan antikanker. Namun mekanisme antidiabetes pada tanaman ini belum ditentukan. Salah satu varietas bawang merah di Indonesia adalah varietas Bima Brebes. Penelitian ini dilakukan untuk menguji potensi ekstrak air dan etanol umbi lapis A. ascalonicum pada konsentrasi $1 \%$ sebagai inhibitor enzim $\alpha$-glukosidase dan dibandingkan aktivitasnya dengan akarbosa $1 \%$ sebagai kontrol positif. Umbi lapis A. ascalonicum diekstraksi dengan menggunakan metode maserasi. Ekstrak air dan etanol dianalisis kandungan fitokimia dan daya inhibisinya terhadap enzim $\alpha$-glukosidase secara metode in vitro. Aktivitas $\alpha$-glukosidase ditentukan dengan mengukur produk $\mathrm{p}$ nitrofenol yang dihasilkan dari reaksi enzim dan substrat p-nitrofenil- $\alpha$-D-glukopiranosida ( $\mathrm{p}$ NPG) menggunakan microplate absorbance reader pada panjang gelombang $410 \mathrm{~nm}$. Hasil uji fitokimia menunjukkan bahwa ekstrak air umbi lapis A. ascalonicum mengandung flavonoid dan tanin. Selain itu, ekstrak etanol $96 \%$ dan ekstrak etanol $70 \%$ umbi lapis $A$. ascalonicum mengandung flavonoid, tanin, dan saponin. Ekstrak air, etanol 70\%, etanol 96\% umbi lapis A. ascalonicum pada konsentrasi $1 \%(\mathrm{~b} / \mathrm{v})$ dan akarbosa $1 \%$ dapat menginhibisi aktivitas enzim $\alpha$-glukosidase berturut-turut sebesar $11,75 \%, 4,48 \%, 20,92 \%$, dan 99,37\%. Hasil aktivitas inhibisi ketiga ekstrak ini berbeda nyata $(\mathrm{p}<0,05)$ dengan daya inhibisi akarbosa 1\%. Hal ini mengindikasikan bahwa ekstrak air dan etanol umbi lapis $A$. ascalonicum berperan sebagai inhibitor enzim $\alpha$-glukosidase.
\end{abstract}

Kata kunci: Allium ascalonicum, $\alpha$-glukosidase, akarbosa, inhibitor enzim

\section{INHIBITION ACTIVITY $\alpha$-GLUCOSIDASE ENZYME FROM WATER AND ETHANOL EXTRACT OF BIMA BREBES VARIETIES RED ONION (Allium ascalonicum) BULBS WITH IN VITRO ASSAY}

\begin{abstract}
Shoot bulbs (Allium ascalonicum) has potential as an analgesic, antiinflamation, antimycobacterial, antifungi, and anticancer. However the mechanism of antidiabetic at the plant has not been determined. One of the varieties of red onion in Indonesia are varieties of Bima Brebes. This research was conducted to test the potential of water and ethanol extracts of A. Ascalonicum bulbs at a concentration of $1 \%$ as the $\alpha$-glucosidase enzyme inhibitors and compared its activities with $1 \%$ acarbose as a positive control. Bulbs of A. ascalonicum extracted by maceration method. Water and ethanol extracts analyzed the content of phytochemical assay and inhibition power of $\alpha$-glucosidase used in vitro method. The $\alpha$ glucosidase activity is determined by measuring the $p$-nitrophenol which is produced from the reaction of the enzyme and $p$-nitrophenyl- $\alpha$-D-glucopyranoside ( $p$-NPG) substrate using microplate absorbance reader at $410 \mathrm{~nm}$ wavelength. The phytochemical result showed that water exctract of $A$. ascalonicum bulbs contains flavonoid and tannin. Beside that, ethanol
\end{abstract}


96\% and ethanol 70\% extract of A. ascalonicum bulbs contain flavonoid, tannin, and saponin. Extracts of water, $70 \%$ ethanol, $96 \%$ ethanol of $A$. ascalonicum bulbs at $1 \%$ concentration and $1 \%$ acarbose inhibits $\alpha$-glucosidase enzyme activity in a row of $11.75 \%, 4.48 \%, 20.92 \%$, and $99.37 \%$. Results of the third extract inhibition activity were significantly different $(\mathrm{p}<$ $0.05)$ to inhibition activity of $1 \%$ acarbose. This indicates that the water and ethanol extracts of $A$. ascalonicum bulbs act as an inhibitor of $\alpha$-glucosidase enzyme.

Key words: Allium ascalonicum, $\alpha$-glucosidase, acarbosa, enzyme inhibitor

\section{PENDAHULUAN}

Seiring dengan perubahan gaya hidup yang dilakukan masyarakat terutaman dalam hal pola makan secara tidak langsung dapat memicu timbulnya berbagai penyakit generatif dan kronis, salah satunya adalah diabetes melitus (DM). Diabetes melitus merupakan penyakit yang ditandai dengan peningkatan kadar gula dalam darah melebihi kadar normal atau hiperglikemia. Hiperglikemia disebabkan oleh adanya gangguan sistem metabolisme dalam tubuh, terutama akibat organ pankreas tidak mampu memproduksi hormon insulin sesuai kebutuhan tubuh. Menurut Wilds et al., (2004), jumlah penderita diabetes melitus di dunia tahun 2000 mencapai 177 juta orang dan diperkirakan meningkat menjadi 370 juta pada tahun 2030. Sebagian besar penderitanya merupakan kasus diabetes melitus tipe 2 yang berkaitan dengan obesitas. Jumlah orang yang terdiagnosa diabetes melitus di Indonesia sebanyak 8,4 juta jiwa dan menempati urutan terbesar keempat di dunia setelah India, Cina dan Amerika. Pada tahun 2030 diperkirakan penderita diabetes melitus di Indonesia mencapai 21,3 juta orang.

Pengobatan diabetes melitus dapat dilakukan dengan pemberian injeksi insulin atau menggunakan obat-obatan modern, seperti antidiabetik oral yaitu sulfonilurea, biguanid, thiazolidindion dan penghambatan $\alpha$-glukosidase. Obat-obatan penghambat enzim $\alpha$-glukosidase digunakan untuk diabetes melitus tipe 2. Tipe obat ini tidak meningkatkan sekresi insulin. Penggunaan obat antihiperglikemik penghambat enzim $\alpha$-glukosidase bekerja menginhibisi secara reversibel, berkompetisi dengan enzim pencernaan karbohidrat di usus seperti $\alpha$ - amilase, $\alpha$-glukosidase, sukrase dan maltase. Enzim-enzim ini bekerja dengan menghidrolisis karbohidrat menjadi glukosa. Pada pasien diabetes melitus, penghambatan terhadap enzim ini menyebabkan peghambatan terhadap absorbsi glukosa dan menurunkan hiperglikemia.

Bawang merah (Allium ascalonicum) merupakan famili Liliaceae yang biasa digunakan untuk bumbu masak dan obat tradisional. Umbi lapis dari A. ascalonicum mempunyai potensi sebagai analgesik dan antiinflamasi (Owoyele et al., 2006), antimikobakterial (Amin et al., 2009), antifungi (Mahmoudabadi \& Nasery, 2009), dan sebagai antikanker (MohammadiMotlagh et al., 2011).

Penelitian umbi lapis A. ascalonicum sebagai antidiabetes yang telah dilakukan antara lain oleh Kouhsari, S.M. and Sani, M.F. (2011) menyatakan bahwa pemberian ekstrak metanol $A$. ascalonicum dengan dosis 250 dan $500 \mathrm{mg} / \mathrm{kg}$ BB secara peroral kepada tikus yang terinduksi diabetes melitus akan mereduksi kadar glukosa darah postprandial serta meningkatkan ekspresi gen Ins dan Glut4. Selain itu, pemberian ekstrak tersebut dapat menginhibisi aktivitas enzim sukrase dan maltase pada usus tikus yang terinduksi diabetes melitus. Menurut Luangpirom, et al. 2013, ekstrak jus umbi lapis A. ascalonicum dapat menurunkan kadar gula darah setelah 14 hari pemberian secara oral pada tikus yang terinduksi diabetes melitus. Penurunan kadar gula darah sebesar $43,45 \%$ dan $59,18 \%$ dengan dosis ekstrak masing-masing $0,5 \mathrm{~g} / 100 \mathrm{~g}$ bb dan $1 \mathrm{~g} / 100 \mathrm{~g}$ bb. Penurunan kadar gula darah ini disebabkan oleh inhibisi aktivitas enzim $\alpha$ - 
glukosidase sehingga memperlambat penyerapan karbohidrat postprandial.

Beberapa varietas bawang merah yang sudah ada di Indonesia pada tahun 1984 adalah varietas Bima Brebes, varietas Medan, varietas Kling dan varietas Maja Cipanas. Jenis tanaman tersebut cukup dominan diusahakan petani di daerahdaerah sentra produksi maupun yang sedang berkembang. Sedangkan jenis bawang merah unggul lokal yang banyak diusahakan petani adalah Kuning, Kuning Gombong, dan Sumenep (Putrasamedja \& Suwandi, 1996).

Di Indonesia tanaman bawang merah telah lama diusahakan oleh petani sebagai usaha tani komersial. Beberapa varietas (Probolinggo, Bima, Tiron sawah, Tiron pasir,Biru sawah, Biru pasir, Parman, Bima, dan kuning) merupakan varietas yang tumbuh baik di lingkungan dengan produktivitas yang tinggi. Varietas Parman dan Kuning paling stabil dapat tumbuh di daerah sawah dan pada musim kemarau (Erlina \& Yudono, 2003).

Ekstrak polar dari umbi lapis $A$. ascalonicum mengandung furostanol, saponin, kuersetin, isorhamnetin, dan glikosida (Fattorusso et al., 2002). Senyawa bioaktif tersebut diduga memiliki aktivitas inhibisi terhadap enzim $\alpha$-glukosidase sehingga dapat berpotensi sebagai antidiabetes. Berdasarkan penelitian tersebut, maka penelitian ini bertujuan untuk menguji daya inhibisi ekstrak polar (air, etanol 96\%, dan etanol 70\%) umbi lapis A. ascalonicum varietas Bima Brebes terhadap aktivitas enzim $\alpha$-glukosidase dengan akarbosa sebagai kontrol positif.

\section{METODE PENELITIAN}

Penelitian ini dilaksanakan pada bulan April sampai Juni 2013 bertempat di Laboratoium STTIF (Sekolah Tinggi Teknologi Industri dan Farmasi) Bogor dan Pusat Studi Biofarmaka LPPM IPB.

\section{Bahan}

Umbi lapis bawang merah (Gambar 1), akuades, etanol $96 \%$, etanol $70 \%, \alpha$ glukosidase (Sigma G 3651-250UN), p- nitrofenil $\alpha$-D-glukopiranosida (p-NPG) (Sigma N 1337-5G), tablet Glucobay (Akarbosa) (Bayer, Jakarta- Indonesia), $\mathrm{HCl}$ 2 N, Dimetilsulfoksida (DMSO), Larutan $\mathrm{Na}_{2} \mathrm{CO}_{3}$, Serum Bovin Albumin (SBA), buffer fosfat $\mathrm{pH} 7$.

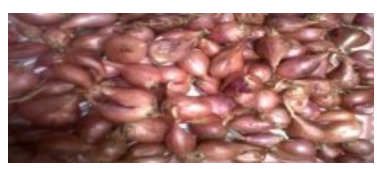

Gambar 1. Bawang merah varietas Bima Brebes

\section{Alat}

Alat-alat ekstraksi, neraca analitik, alat-alat kaca, penguap putar (rotary evaporator) (BUCHI, R-250, Switzerland), perangkat instrumen microplate reader (Epoch Microplate Spectrophotometer), alat microplate (Thermo Scientific NUNC) dan micropipet (Thermo Scientific).

\section{Cara Kerja}

\section{Ekstraksi}

Ekstraksi menggunakan metode maserasi selama 1 x 24 jam dengan cairan penyari yang bersifat polar yaitu akuades, etanol 96\%, dan etanol $70 \%$. Proses maserasi dilakukan dengan sebanyak 10 gram simplisia umbi lapis A. ascalonicum direndam dengan masing-masing $100 \mathrm{ml}$ pelarut akuades, etanol $96 \%$ dan etanol $70 \%$ selama $1 \mathrm{x}$ 24 jam pada suhu kamar didalam maserator. Selanjutnya rendaman disaring menggunakan kertas saring halus dan filtratnya disimpan. Masingmasing filtrat yang diperoleh dipekatkan dengan penguap putar (rotavapor) pada suhu $40^{\circ} \mathrm{C}$ sehingga diperoleh ekstrak (air, etanol 96\%, dan etanol 70\%). Ekstrak yang telah dipekatkan selanjutnya dilakukan uji aktivitas inhibisi $\alpha$-glukosidase dan penapisan fitokimia.

2. Penapisan Fitokimia (Harbone, 1987) Penapisan fitokimia ekstrak air, etanol $96 \%$, dan etanol $70 \%$ umbi lapis $A$. ascalonicum. 
3. Uji Inhibisi $\alpha$-Glukosidase

Tabel 1. Proses Uji Inhibisi $\alpha$ Glukosidase (Sancheti. et al., 2009)

\begin{tabular}{|c|c|c|}
\hline & $\begin{array}{l}\text { S0 } \\
(\mu \mathrm{L})\end{array}$ & $\mathrm{S} 1(\mu \mathrm{L})$ \\
\hline Ekstrak & 50 & 50 \\
\hline Dapar Fosfat & 50 & 50 \\
\hline p-NPG & 25 & 25 \\
\hline Dapar Fosfat & 25 & - \\
\hline$\alpha$-Glukosidase & - & 25 \\
\hline \multicolumn{3}{|c|}{ Inkubasi pada suhu $37^{\circ} \mathrm{C}$ selama 30 menit } \\
\hline $\mathrm{Na}_{2} \mathrm{CO}_{3}$ & 100 & 100 \\
\hline \multicolumn{3}{|c|}{$\begin{array}{l}\text { Diukur dengan microplate reader pada } \lambda= \\
410 \mathrm{~nm}\end{array}$} \\
\hline \multicolumn{3}{|c|}{$\begin{array}{ll}\text { Keterangan: } & \text { S0 = kontrol negatif } \\
& \text { S1 }=\text { sampel }\end{array}$} \\
\hline
\end{tabular}

Sampel yang diuji dilarutkan dalam DMSO kemudian dicukupkan volumenya dengan dapar fosfat $\mathrm{pH} 7$ sehingga didapatkan larutan ekstrak dengan konsentrasi $1 \% \quad(\mathrm{~b} / \mathrm{v})$. Setelah ditambahkan dapar fosfat $100 \mathrm{mM}$, dan larutan substrat p-NPG $0,5 \mathrm{mM}$, diinkubasi selama 30 menit kemudian ditambahkan $\mathrm{Na}_{2} \mathrm{CO}_{3} 200 \mathrm{mM}$ lalu larutan diukur absorbansinya pada $\lambda 410$ nm (Sancheti et al., 2009). Kontrol positif menggunakan akarbosa $1 \%(\mathrm{~b} / \mathrm{v})$. Persentase daya hambat dihitung dengan persamaan:

$$
\% \text { inhibisi }=\frac{(C-S)}{C} \times 100 \%
$$

Keterangan :

$\mathrm{S}$ : absorbansi sampel $\left(\mathrm{S}_{1}-\mathrm{S}_{0}\right)$

$\mathrm{S}_{1}$ : absorbansi sampel dengan penambahan enzim

$\mathrm{S}_{0}$ : Absorbansi sampel tanpa enzim

$\mathrm{C}$ : absorbansi larutan kontrol (DMSO) tanpa sampel (kontrol-blanko).

\section{Analisis Data}

Data aktivitas inhibisi $\alpha$ glukosidase yang diperoleh dalam penelitian ini dianalisis secara statistik menggunakan ANOVA yaitu RAL (Rancangan Acak Lengkap) satu faktor dengan tiga kali ulangan pada tingkat kepercayaan $95 \%$ dan taraf $\alpha 0,05$ dan kemudian dilanjutkan dengan uji
DUNCAN. Pengolahan data dengan SPSS 14. Model rancangan tersebut :

$$
\mathrm{Y}_{\mathrm{ij}}=\mu+\tau_{\mathrm{i}}+\varepsilon_{\mathrm{ij}}
$$

Keterangan:

Yij = Nilai pengamatan faktor perlakuan ekstrak taraf ke-i dan ulangan ke-j.

$\mu=$ Rataan umum

$\tau i=$ Pengaruh utama perlakuan ekstrak ke-i.i $=1,2,3,4,5$

$\mathrm{i}=1$ adalah blanko

$\mathrm{i}=2$ adalah ekstrak air bawang merah $1 \%$

$\mathrm{i}=3$ adalah ekstrak etanol $96 \%$ bawang merah $1 \%$

$\mathrm{i}=4$ adalah ekstrak etanol $70 \%$ bawang merah $1 \%$

$\mathrm{i}=5$ adalah pembanding atau kontrol positif akarbosa $1 \%$

$\varepsilon \mathrm{ij}=$ pengaruh acak yang menyebar normal pada perlakuan ke-i dan ulangan ke-j. J = 1, 2, 3

\section{HASIL DAN PEMBAHASAN}

Bahan umbi bawang merah (A. ascalonicum) varietas Bima Brebes berumur 2 bulan dan diambil dari daerah Brebes, Jawa Tengah. Umbi A. ascalonicum yang akan diekstraksi dibuat serbuk terlebih dahulu, ini bertujuan agar proses penyarian zat aktif lebih maksimal. Semakin kecil atau halus ukuran bahan yang digunakan maka semakin luas bidang kontak antara bahan dengan pelarutmya, hal ini dapat meningkatkan efektivitas ekstraksinya. Metode ekstraksi yang digunakan untuk mengekstraksi sampel adalah metode maserasi menggunakan air dan etanol absolut. Pemililhan pelarut etanol berdasarkan pendapat Harbone (1987) yang menyatakan bahwa bahan segar dapat diekstraksi menggunakan alkohol absolut. Mekanisme metode maserasi yaitu adanya difusi pelarut kedalam dinding sel tumbuhan untuk mengekstrak senyawa-senyawa yang kurang tahan terhadap pemanasan.

Hasil maserasi yang diperoleh diuapkan dengan menggunakan rotavapor pada suhu $40^{\circ} \mathrm{C}$. Suhu yang digunakan tidak boleh terlalu tinggi karena dapat merusak 
senyawa yang terdapat dalam simplisia. Ekstrak kental yang dihasilkan ditimbang untuk mendapatkan rendemen. Rendemen ekstrak dan hasil fitokimia dapat dilihat pada Tabel 2.

Tabel 2. Hasil Ekstraksi Umbi Lapis $A$. ascalonicum varietas Bima Brebes

\begin{tabular}{|c|c|c|c|}
\hline No & Ekstrak & $\begin{array}{c}\text { Bobot } \\
\text { (g) }\end{array}$ & $\begin{array}{c}\text { Rendemen } \\
(\%)\end{array}$ \\
\hline 1 & Ekstrak air & 3,83 & 38,27 \\
\hline 2 & $\begin{array}{l}\text { Ekstrak etanol } \\
70 \%\end{array}$ & 2,76 & 27,49 \\
\hline 3 & $\begin{array}{l}\text { Ekstrak etanol } \\
96 \%\end{array}$ & 1,54 & 15,35 \\
\hline
\end{tabular}

Rendemen ekstrak yang tertinggi berada pada ekstrak air yaitu sebesar $38,72 \%$ atau sama dengan 3,83 g ekstrak dalam $10 \mathrm{~g}$ simplisia umbi lapis A. ascalonicum. Selanjutnya rendemen ekstak etanol $70 \%$ dan ekstrak etanol $96 \%$ berturut-turut sebesar $27,49 \%$ dan $15,35 \%$. Ekstrak yang diperoleh selanjutnya dilakukan analisis fitokimia dan uji aktivitas inhibisi $\alpha$-glukosidase.

\section{Hasil Uji Fitokimia}

Hasil analisis fitokimia terhadap ekstak air dan etanol umbi lapis $A$. ascalonicum varietas Bima Brebes disajikan pada Tabel 3. Berdasarkan uji fitokimia diperoleh bahwa ekstrak air mengandung flavonoid, dan tanin. Sedangkan pada ekstrak etanol $96 \%$ dan etanol $70 \%$ mengandung flavonoid, tanin, dan saponin. Jenis senyawa fitokimia yang menonjol pada ekstrak etanol 96\% (flavonoid, tanin, dan saponin) lebih banyak dibandingkan yang ditemukan pada ekstrak etanol $70 \%$.

Skrining fitokimia ekstrak air dan etanol umbi lapis A. ascalonicum menunjukkan hasil positif pada uji flavonoid dan tanin. Flavonoid memiliki gugus hidroksi yang tidak tersubstitusi sehingga bersifat polar dan tanin termasuk golongan polifenol yang bersifat polar. Oleh sebab itu, pelarut polar seperti air dan etanol dapat menarik senyawa yang bersifat polar. Pada ekstrak etanol $70 \%$ dan $96 \%$ umbi lapis $A$. ascalonicum menunjukkan hasil positif pada uji saponin. Saponin memiliki gugus glikosil yang berfungsi sebagai gugus polar dan gugus steroid sebagai gugus non polar. Pada ekstrak air tidak dideteksi adanya saponin karena air bersifat lebih polar dibandingkan etanol $70 \%$ dan etanol $96 \%$ sehingga tidak mampu menarik senyawa yang bersifat semipolar. Hal ini sesuai dengan Fattorusso et al. (2002) mengungkapkan bahwa ekstrak polar dari umbi lapis A. ascalonicum mengandung furostanol, saponin, kuersetin, isorhamnetin, dan glikosida.

Tabel 3. Data Hasil Pemeriksaan Fitokimia Ekstrak Air, Ekstrak Etanol 70\%, dan Ekstrak Etanol 96\% Umbi Lapis A. ascalonicum varietas Bima Brebes

\begin{tabular}{cccc}
\hline Golongan & $\begin{array}{c}\text { Ekstrak } \\
\text { Air }\end{array}$ & $\begin{array}{c}\text { Ekstrak } \\
\text { Etanol } \\
\mathbf{7 0 \%}\end{array}$ & $\begin{array}{c}\text { Ekstrak } \\
\text { Etanol } \\
\mathbf{9 6 \%}\end{array}$ \\
\hline Alkaloid & - & - & - \\
Flavonoid & ++ & ++ & +++ \\
Tanin & +++ & ++ & +++ \\
Saponin & - & + & +++ \\
Triterpenoid & - & - & - \\
Steroid & - & - & - \\
\hline Keterangan: & $(-)=$ tidak terdeteksi, $(+)=$ \\
& terdeteksi & sedikit, $(++)=$ \\
& terdeteksi sedang, dan $(+++)=$ \\
& terdeteksi banyak.
\end{tabular}

\section{Hasil Uji Inhibisi $\alpha$-Glukosidase}

Uji inhibisi terhadap enzim $\alpha$ glukosidase menggunakan sampel ekstrak air, ekstrak etanol $70 \%$ dan ekstrak etanol 96\% umbil lapis A. ascalonicum varietas Brebes. Masing-masing sampel dibuat konsentrasi sebesar $1 \%(\mathrm{~b} / \mathrm{v})$. Kontrol positif menggunakan akarbosa $1 \% \quad(\mathrm{~b} / \mathrm{v})$. Konsentrasi sampel dibuat setara dengan konsentrasi kontrol positif guna membandingkan aktivitas inhibisi enzim $\alpha$ glukosidase oleh sampel maupun akarbosa. Dari hasil penelitian yang telah dilakukan menunjukkan bahwa ekstrak air, ekstrak etanol $96 \%$ dan ekstrak etanol $70 \%$ umbil lapis A. ascalonicum mampu menghambat aktivitas enzim $\alpha$-glukosidase. Gambar 2 menunjukkan aktivitas inhibisi enzim $\alpha$ glukosidase oleh ekstrak air, ekstrak etanol $70 \%$, ekstrak etanol 96\%, dan akarbosa $1 \%$. 


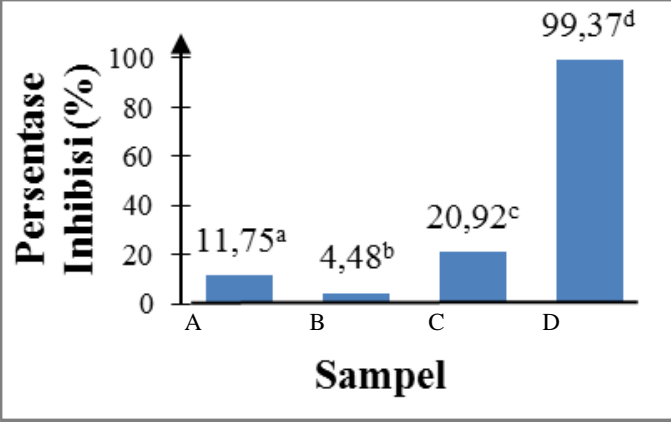

Gambar 2. Aktivitas inhibisi enzim $\alpha$ glukosidase umbi lapis $A$. ascalonicum

Keterangan: $\mathrm{A}=$ ekstrak air, $\mathrm{B}=$ ekstrak etanol70\%, C= ekstrak etanol $70 \%, \mathrm{D}=$ Akarbosa 1\%. Huruf kecil yang berbeda menunjukkan nilai beda nyata pada $\mathrm{p}<0,05$.

Ekstrak etanol $96 \%$ umbi lapis $A$. ascalonicum $1 \%$ (b/v) mampu menginhibisi aktivitas $\alpha$-glukosidase dengan rerata sebesar $20,92 \%$ kemudian daya inhibisi yang dihasilkan oleh ekstrak air umbi lapis $A$. ascalonicum $1 \%(\mathrm{~b} / \mathrm{v})$ dengan rerata sebesar $11,75 \%$ sedangkan daya inhibisi yang dihasilkan oleh ekstrak etanol $70 \%$ umbi lapis A. ascalonicum $1 \%(\mathrm{~b} / \mathrm{v})$ dengan rerata sebesar 4,48\%. Larutan kontrol positif (akarbosa) menghasilkan daya inhibisi aktivitas $\alpha$-glukosidase dengan rerata sebesar 99,37\%. Daya inhibisi yang terbesar ditunjukkan oleh akarbosa yang merupakan inhibitor $\alpha$-glukosidase dan sudah digunakan sebagai obat diabetes mellitus dengan mekanismenya penghambatan aktivitas $\alpha$ glukosidase. Ekstrak etanol 96\% umbi lapis A.ascalonicum $1 \%$ (b/v) memiliki daya inhibisi yang lebih tinggi dibandingkan dengan ekstrak lainnya, hal ini dikarenakan senyawa yang bersifat antidiabetes seperti saponin, flavonid, dan tannin secara kualitatif lebih banyak terkandung di dalam ekstrak etanol $96 \%$.

Data aktivitas inhibisi $\alpha$-glukosida dianalisis statistik menggunakan ANOVA dan taraf $\alpha=0.05$ yang menunjukkan bahwa pemberian ekstrak air, ekstrak etanol $96 \%$ dan ekstrak etanol $70 \%$ umbi lapis $A$. ascalonicum dapat menghambat aktivitas inhibisi $\alpha$-glukosidase dengan aktivitas inhibisi $\alpha$-glukosidase yang berbeda nyata $(\mathrm{p}<0,05)$ satu sama lain. Aktivitas inhibisi tertinggi dari ekstrak etanol $96 \%$ sebesar $20,92 \%$ berbeda nyata dengan aktivitas inhibisi akarbosa $1 \%$ sebesar 99,37\%. Oleh karena itu, aktivitas inhibisi $\alpha$-glukosidase oleh ekstrak etanol $96 \%$ umbi lapis $A$. ascalonicum $1 \%$ belum setara aktivitasnya dengan akarbosa $1 \%$. Hal ini diduga aktivitas antidiabetes yang dimiliki ekstrak tersebut mekanismenya tidak sepenuhnya berdasarkan pada enzim $\alpha$-glukosidase.

Analisis fitokimia menunjukkan bahwa ekstrak etanol $96 \%$ umbi lapis $A$. ascalonicum mengandung senyawa flavonoid yang ditandai dengan tingginya intensitas warna merah tua pada uji flavonoid. Melalui analisis tersebut dapat diperkirakan komponen aktif yang menghambat aktivitas $\alpha$-glukosidase adalah flavonoid. Menurut Tan et.al. (2013) komponen fenolik seperti kuersetin, rutin, kaemferol-3-O- $\beta$-D-glukopiranosida,

kaemferol-3-O-rutinosida, dan 3,5dicaffeoylquinic acid methyl ester) dapat menginhibisi $\alpha$-glukosidase. Kemampuan aktivitas inhibitor $\alpha$-glukosidase yang dimiliki oleh ekstrak air dan etanol umbi lapis A. ascalonicum tidak lepas dari kerja senyawa fitokimia yang dikandungnya. Tingginya aktivitas inhibisi $\alpha$-glukosidase pada ekstrak etanol $96 \%$ dibandingkan dengan ekstrak air dan ekstrak etanol $70 \%$ adalah sejalan dengan hasil yang ditunjukkan secara kualitatif pada penapisan fitokimia dimana jenis senyawa yang menonjol ditemukan pada ekstrak etanol 96\%.

\section{SIMPULAN DAN SARAN \\ Simpulan}

Ekstrak air umbi lapis A. ascalonicum varietas Bima Brebes mengandung flavonoid dan tanin. Sedangkan ekstrak etanol $96 \%$ serta esktrak etanol $70 \%$ umbi lapis $A$. ascalonicum varietas Bima Brebes mengandung flavonoid, tanin, dan saponin. Ketiga ekstrak tersebut mampu menginhibisi aktivitas enzim $\alpha$-glukosidase secara in vitro. Daya inhibisi $\alpha$-glukosidase oleh ekstrak air, 
ekstrak etanol 70\%, dan ekstrak etanol 96\% umbi lapis A. ascalonicum $1 \%$ (b/v) berturutturut sebesar $11,75 \%, 4,48 \%$, dan $20,92 \%$. Ketiga aktivitas inhibisi tersebut berbeda nyata dengan aktivitas inhibisi $\alpha$-glukosidase oleh akarbosa $1 \%$ sebesar $99,37 \%$.

\section{Saran}

Penelitian dapat dilanjutkan dengan meningkatkan konsentrasi ekstrak etanol 96\% umbi lapis A. ascalonicum varietas Bima Brebes guna meningkatkan daya inhibisi enzim $\alpha$-glukosidase. Pemurnian ekstrak dari ekstrak etanol $96 \%$ umbi lapis $A$. ascalonicum diperlukan untuk memperoleh senyawa aktif yang berperan sebagai antidiabetes. Selain itu, perlu dilakukan pengujian antidiabetes dengan metode lain sehingga dapat diketahui mekanisme kerja ekstrak umbi lapis A. ascalonicum varietas Bima Brebes sebagai obat antidiabetes.

\section{DAFTAR PUSTAKA}

Amin, M., Segatoleslami, S., and Hashemzadeh, M. 2009. Antimycobacterial activity of partial purified extract of Allium ascalonicum. Jundishpur Journal of Microbiology. 2 (4): 144-147.

Erlina, A., dan Yudono, P. 2003. Keragaan stabilitas hasil bawang merah. The performance of yield stability of shallot. Ilmu Pertanian. 10 (2):1-10.

Fattorusso, E., Iorizzi, M., Lanzotti, V., and Taglialatela-Scafati, O. 2002. Chemical composition of shallot (Allium ascalonicum Hort.). J. Agric. Food Chem. 50 (20): 5686-5690.

Harborne, J.B. 1987. Metode Fitokimia, Penuntun Cara Modern Menganalisis Tumbuhan. Bandung: Penerbit ITB.

Kouhsari, S.M and Sani, M.F. 2011. Antidiabetic effects of Allium ascalonicum methanolic extract in experimental diabetes. Planta Med. 77: 87.

Luangpirom, A., Kourchampa, W., Junaimuang, T., Somsapt, P., and Sritragool, O. 2013. Effect of Shallot (Allium ascalonicum L.) bulb juice on hypoglycemia and sperm quality instreptozotocin induced diabetic mice. ABAH Bioflux. 5 (1): 49-54.

Mahmoudabadi, A.Z., and Nasery, M.K.B. 2009. Anti fungal activity of Shallot, Alium ascalonicum Linn. (Liliaceae), In vitro. Journal of Medicinal Plants Research 3 (5): 450-453.

Mohammadi-Motlagh, H-R, Mostafaie, A, and Mansouri, K. 2011. Anticancer and anti-inflammatory activities of Shallot (Allium ascalonicum) extract. Arch Med Sci. 7 (1): 38-44.

Owoyele, B.V., Abioye, A.I.R, Afinowi, N.O, Jimoh, S.S, and Soladoye, A.O. 2006. Analgesic and anti-inflamatory effects of Allium ascalonicum. The Tropical Journal of Health Sciences. 13 (1): 28-30.

Putrasamedja, S., dan Suwandi.1996. Bawang Merah di Indonesia. Monograf No. 5: 1-23.

Sancheti, S., Sancheti, S., and Seo, S.Y. 2009. Chaenometes sinensis a potent $\alpha$ and $\beta$ - Glucosidase inhibitor. America Journal of Pharmacology and Toxicology. 4(1): 8-11.

Tan, C., Wang, Q., Luo, C., Chen, S., Li, Q., and Li. P. 2013. Yeast $\alpha$-Glucosidase inhibitory phenolic compounds isolated from Gynura medica leaf. Int.J. Mol. Sci. 14: 2551-2558.

Wilds, S., Roglic, G., Green, A., Sincre, R., and King, H. 2004. Global prevalence of diabetes: estimates for the year 2000 and projections for 2030. Diabetes Care 27: 1047-1053. 